\title{
The "Winter of Native Discontent": \\ A Critical Discourse Analysis of Canadian Opinion Journalism on the Idle No More Movement
}

\author{
Tiffany Campbell
}

\begin{abstract}
Aboriginal activism has become increasingly subject to media publicity, reflecting a popular view of Aboriginals not only as a social problem but as creating problems that threaten the social fabric. This paper is based on the findings of a critical discourse analysis of a collection of opinion pieces published in The Globe and Mail and the National Post. The contemporary construction of the "Indian problem" was investigated in the context of the Idle No More movement, viewing these texts as part of larger processes of elaboration, articulation, and application of Western ideas on Aboriginal social policy. One of the fundamental conflicts that can be identified in settler discourse is in regard to history and change and a particular concern with how much of the past should be carried into the future. The discontinuous view of history emphasizes the distance of history, making the past seem foreign to the modern, civilized eye. Injustices are presented as characteristics of history, and the violence of colonial times can be disconnected from the present.
\end{abstract}

$\mathrm{O}_{\mathrm{p}}^{\mathrm{n}}$ December 24, 2012, the National Post published a special article by Métis lawyer Chelsea Vowel entitled "No, things are not getting better for Canadian Natives." Vowel argued that, when thousands of Indigenous people across Canada rallied together under the banner of Idle No More, the mainstream media misrepresented their actions by focusing on politics and legislative grievances such as the omnibus Bill C-45. She wrote:

What it all boils down to is this. Canada has not committed itself to addressing the colonial relationship it still has with indigenous peoples. Canada is in denial about that relationship. I think it's fair to say that most Canadians believe that kind of relationship no longer exists. We are trying to tell you that you are wrong.

The inception of the Idle No More movement was in the final month of 2012 following the Jobs and Growth Act (Bill C-45), which made changes to the Canadian Environmental Assessment Act, the Fisheries Act, the Navigable Waters Protection
Act, and the proposed Safe Drinking Water for First Nations Act-all of which have profound implications for the rights of Indigenous peoples. The various actions of the movement, which has continued over a year later, included flash mob round dances, rallies, marches, educational events, hunger strikes and in some places blockades, and has played a supportive role ${ }^{1}$ at local actions from the Mi'kmaq stand-off against shale gas exploration, to marches for missing and murdered Aboriginal women, to the Unist'ot'en pipeline resistance camp in British Columbia. Though the Conservative Bill acted as a catalyst, it is clear that this new wave of indigenous activism is part of a long history of indigenous struggle in North America.

In the comments section that followed in the online edition of Vowel's article, the highestrated comment was by one Anonymous66, who replied:

You can't demand strict adherence to "nation to nation" treaties AND simultaneous equality with other Canadians real nations take care of their own rather

\footnotetext{
${ }^{1}$ These actions were affiliated, in part, through their identification with Idle No More as a national and more broadly international Indigenous peoples movement. You could therefore say that Idle No More is a rallying cry, or a larger banner of solidarity with anti-colonial activism across the country and even globally.
}

\section{Graduate student; Department of Anthropology, University of Alberta Author contact: tmcampbe@ualberta.ca}

Diversipede, Vol. 2, No. 1, pp. 32-46, 2016 
than harass another nation to fund their needs... If you want equality with every other Canadian in those areas, you're going to have to put all the inequalities that work in your favour on the table as well, and renegotiate a new deal from scratch.

Although the comments sections of online media outlets are not known for their erudite responses, I would argue that Anonymous66's exegesis is more typical than troll. ${ }^{2}$ The commenter's short analysis reveals an ideological topography upon which those engaging in Indigenous activism and Aboriginal ${ }^{3}$ politics are often forced to tread. These discourses carry with them particular existential, propositional, and value assumptions that should not be taken for granted by writers and readers.

The ideological effects of texts in inculcating and sustaining or changing ideologies have been of major concern for critical discourse analysts and social theorists (e.g., Fairclough and Wodak 1997; Fowler et al. 1979; Hall 1982; Kress et al. 1979; Shapiro 1981; van Dijk 1998; Wetherell and Potter 1992). Fairclough (2003, 9) writes that ideologies are "representations of aspects of the world which can be shown to contribute to establishing, maintaining and changing social relations of power, domination and exploitation." Although the anonymous commenter's version is but one, and its influence upon readers perhaps questionable, it is part of larger processes of elaboration, articulation, and application of Western ideas on Aboriginal social policy. For instance, let us look at another text (in Leslie 1978, 114):

I want to get rid of the Indian problem. I do not think as a matter of fact, that the country ought to continuously protect a class of people who are able to stand alone... Our objective is to continue until there is not a single Indian in Canada that has not been absorbed into the body politic and there is no Indian question, and no Indian Department, that is the whole object of this Bill.

This is an infamous 1920 quote by Duncan Campbell Scott, ${ }^{4}$ made in reference to Bill 14 which would amend the Indian Act, mandating Aboriginal children to attend residential schools. There are a number of parallels between Scott's argument and Anonymous66's. Why the symmetry between the words of an elite government bureaucrat, almost 100 years ago, and an anonymous internet commenter on an article about a contemporary grassroots indigenous peoples' movement?

The purpose of my research was to document and analyze settler Canadian ${ }^{5}$ discourses surrounding the various actions of the Idle No More movement. Using critical discourse analysis, I examined a collection of 30 opinion pieces published in The Globe and Mail and the National Post (Blatchford 2012; Brazeau 2013; Carlson 2013; Coates 2013; Coyne 2013a, 2013b; Flanagan 2012, 2013; Foster 2013; Gagnon 2013; Gibson 2013; Gurney 2013; Ibbitson 2013a, 2013b, 2013c, 2013d; Ivison 2013a, 2013b; Jonas 2013; Kay 2013a, 2013b; Martin 2013; McParland 2013a, 2013b, 2013c; Murphy 2013; Saunders 2013; Simpson 2013a, 2013b; Widdowson 2013) to investigate the contemporary construction of the "Indian problem" in the context of Idle No More. The rhetorical strategies of the journalists I analyzed tend to mobilize the classic liberal principles of freedom, individual rights, equality, and rationality, along with a historical account of progress, to mount racist arguments. This paper

\footnotetext{
2 "Troll" is internet slang for a person who, usually anonymously, provokes other commenters by posting ad hominem insults and various slurs in order to offend or take over the comments section and derail constructive conversation.

${ }^{3}$ It has been argued (e.g. Alfred 1999; Eudaily 2004) that terms such as Aboriginal, Indian, and Native are convenient bureaucratic terms that do not do justice to the cultural complexity of First Nations and are "negatively defined by the European norm" (Eudaily 2004, 2). Because of its inclusivity, I will use the term Aboriginal to refer to Canadian Indigenous peoples, as well as the term Indigenous when specifically referring to indigenous modes of production, values, governance systems, and international or global resistance movements.

${ }^{4}$ Treaty Commissioner (No. 9) and Head of the Department of Indian Affairs from 1913-1932.

5 "Settler" refers to non-Indigenous persons, practices, and institutions in a colonizing society.
} 
questions how such apparently benign forms of political discourse become regrouped into arguments opposing certain other freedoms, justifying the perceived pattern of Canadian history.

\section{Discourse AND THE Media}

Discourse as an analytic mode has proliferated since Michel Foucault and is now carried out within a variety of scholarly traditions that investigate the relations between language, structure, and agency. In these fields, discourse has generally come to mean somewhat different things (Sawyer 2002), but the key feature is always that language is not simply a tool that neutrally transmits meaning about the objective world from the speaker to the receiver. Rather, it is through discourse that the world is brought into being and objects invested with particular meanings. It is also through discourse that speakers and hearers, writers, and readers come to an understanding about themselves, their relationship to each other, and their place in the world (Ashcroft et al. 1998, 58).

There are several forms of discourse analysis. Critical discourse analysis (CDA) - partly due to its interdisciplinarity and the breadth of its approaches - is widely used across the social sciences. This paper takes its lead, above all, from Wetherell and Potter's (1992) Mapping the Language of Racism: Discourse and the Legitimation of Exploitation, in which the researchers develop a framework for the analysis of racist discourse and conduct an empirical investigation into Pākehā (settler) discourse in New Zealand on Māori protest and social policy. My toolbox for linguistic analysis is taken primarily from the CDA approaches of Norman Fairclough (2003) and, to a lesser extent, Theo van Leeuwen (2007).

Opinion journalism in the mainstream media plays an integral role in public opinion formation. Unlike "hard" news texts, opinion discourses (editorials, op-ed articles, and guest columns) "possess a unique idiomatic character that 'speaks' directly to the readership in a way that is familiar" (Greenberg 2000, 520). They are meant to provide insight through the use of argumentation and personal narrative. Greenberg (2000, 521) writes, "In rendering opinions, laying blame, and presenting solutions about problematic issues, actors and events, opinion writers inevitably accentuate some points of view while downplaying others, thus limiting the range of interpretable meanings available to the public." In such a way, it can be said that these journalists are public opinion-makers, since it is they who define what the problem and the possible appropriate strategies for its solution, and attempt to mobilize and enroll newsreaders around particular ideological positions by resonating in ways that will connect with their ethics and emotions.

\section{Aboriginals and Canadian Newspapers}

Various forms of content and discourse analysis have been utilized in the study of the ways in which Indigenous issues, and Indigenous people themselves, are presented in discourse (e.g. Chrisjohn and Young 2006; Furniss 2001; Grenier 1994; Harding 2006; Henry and Tator 2000, 2002; Miller 2005; Pietikainen 2003; Proulx 2011; Singer 1982; Skea 1993; Szuchewycz, 2000; Teo 2000; Warry 2007; Wetherell and Potter 1992). Non-Indigenous newspapers often reduce the complexity of Indigenous histories to "problems" and mitigate what should be radical discussions by recasting them as matters of incremental bureaucratic policy and procedure. As Taiaiake Alfred $(1999,3)$ writes: "Non-indigenous people have always seen indigenous people in problematic terms: as obstacles to the progress of civilization, wards of the Crown, relics of savagery and dregs of modern society, criminals and terrorists." There have been a number of studies on racism in the Canadian newspaper industry (e.g., Furniss 2001; Harding 2006; Proulx 2011; Skea 1993). For example, following the Oka crisis, ${ }^{6}$ Fleras and Elliot (1992, 9, 92-98) noted that

\footnotetext{
${ }^{6}$ The Oka Crisis was a land dispute between a group of Mohawks and the town of Oka, Quebec, in 1990. The town of Oka was developing plans to expand a golf course and residential development onto traditional Mohawk land, which included pineland and a burial ground, marked by standing tombstones of their ancestors. The Mohawks had filed a land claim for the sacred grove and burial ground near Kanesatake, but their claim had been rejected in 1986. The dispute was the first well-publicized violent conflict between First Nations and the Canadian government in the late 20th century.
} 
First Nations activism was subject to increasing media publicity, reflecting a popular view of $\mathrm{Ab}$ original peoples as “a) a social problem, b) having problems that cost the Canadian taxpayer, and c) creating problems that threaten Canada's social fabric."

In Canada, media ownership is concentrated in a very small handful of corporations. The Globe and Mail, owned predominantly by The Woodbridge Company Limited, is Canada's largest-circulation newspaper. Postmedia Network Inc. owns the National Post, whose columns often appear in the company's other papers such as the Ottawa Citizen, Calgary Herald, Edmonton Journal, Vancouver Sun, and several others.

Idle No More was a top newsmaker in December 2012 and the first few months of 2013, with news coverage and opinion pieces appearing as top stories nearly every day in both papers. I selected articles discussing Aboriginal issues (which included Idle No More), almost all of which were published in the first three weeks of January, 2013. Online publications of the articles were utilized and converted into electronic word documents and sorted by publication date, and were numbered for charting. Specific references to clauses and word choices in the in-text discussion can be found in the two tables appearing at the end of this paper, corresponding to the numbered article list.

In my examination of opinion pieces in The Globe and Mail and the National Post, major patterns, themes, and trends emerged in the representation of contemporary Aboriginal issues. Select portions are presented in this discussion. In the first section of the analysis, I will discuss common referential strategies used by journalists to represent Idle No More activists. This section will be primarily concerned with how protesters, and protests in general, are discredited and delegitimized. The second section will concern how history is articulated in settler journalist accounts to minimize Aboriginal claims for justice.

\section{Discrediting Protest}

In their analysis of Pākehā discourses in New Zealand, Wetherell and Potter (1992, 157158) identified a particular struggle in the rhe- torical effort to delegitimize Māori claims and protest. This struggle required, in the first case, a contrasting account of what they call "the influence process": that is, the establishment of legitimate and illegitimate forms of influence. This struggle is directed towards positioning oneself, those with whom one agrees, and Pākehā politics in general "within the realm of 'proper' influence." Proper influence places emphasis upon "the 'reasonable', the 'rational' and the 'factual'; while Māori groups are positioned within the realm of 'improper' influence, within the 'emotional', the 'social' and the 'irrational"' (Wetherell and Potter 1992, 157-158). In terms of social practice, improper routes tend to be considered social protest and demonstrations, whereas proper routes involve the due process of mainstream institutions.

In the rhetorical procedures of the columnists writing during this period, the particular emphasis placed on moderation, pragmatism and proportion is highly significant. Attempts to develop persuasive arguments in this domain were bolstered primarily through the use of extreme case formulations, classification, evaluative adjectives and "the usual paraphernalia of argumentation," namely seven rhetorical strategies for discrediting protest identified by Wetherell and Potter $(1992,154)$. They note that these argumentative practices were so clear and predictable that they seem to come out of a "recipe book" of rhetorical strategies for discrediting opposing political groups (Wetherell and Potter 1992, 153). Specific references to these strategies in my own data can be found in Table 1.

At the more obvious level of word choice (found in Tables 1 and 2), names were given to Aboriginal protesters in the Idle No More movement: warriors, radicals, extremists, and militants. Their actions and words were also frequently accompanied by evaluative adjectives such as fierce, inflammatory, aggressive, angry, venomous, provocative, and highly charged as well as with nouns such as fury, insurgency, and wrath. These word choices predominately contribute to accusing protesters of violating norms of moderation, presenting them as emotional and extreme. 
Table 1. Common rhetorical strategies used by op-ed columnists in The Globe and Mail and the National Post when writing about Idle No More, December 2012-January 2013.

\begin{tabular}{|c|c|c|}
\hline $\begin{array}{c}\text { Rhetorical } \\
\text { Strategy }\end{array}$ & Article & Examples \\
\hline $\begin{array}{l}\text { Call into ques- } \\
\text { tion genuineness } \\
\text { of opponent's } \\
\text { motives }\end{array}$ & $\begin{array}{l}\text { Blatchford 2012; } \\
\text { Gibson 2013; Ivison } \\
\text { 2013a, 2013b; McPar- } \\
\text { land 2013a, 2013c; } \\
\text { Murphy 2013; Wid- } \\
\text { dowson } 2013\end{array}$ & $\begin{array}{l}\text { "inevitable cycle of hideous puffery" (Blatchford 2012) } \\
\text { "Chief Spence's manufactured dissent" (Foster 2013) } \\
\text { "Theresa Spence... who points the finger of blame at Ottawa with one } \\
\text { hand, while extending the other for more handouts" (Ivison 2013b) } \\
\text { "more worrisome is the tone, the ratcheting up of frictions, and the deliber- } \\
\text { ate forgetting by some" (Murphy 2013) } \\
\text { "Too many native leaders seem bent more on disruption than actual prog- } \\
\text { ress" (McParland } 2013 a \text { ) } \\
\text { "There have been protests in Hawaii (anyone who lives in Hawaii and can } \\
\text { find something to complain about isn't trying very hard)... It's the show } \\
\text { that counts, the protest: being part of the great angry disaffected world } \\
\text { of progressive opposition to The Man" (McParland 2013c) }\end{array}$ \\
\hline $\begin{array}{l}\text { Question ef- } \\
\text { fectiveness of } \\
\text { tactics }\end{array}$ & $\begin{array}{l}\text { Blatchford 2012; } \\
\text { Carlson 2013; Coates } \\
\text { 2013; Coyne 2013a, } \\
\text { 2013b; Gibson 2013; } \\
\text { Foster 2013; Ibbitson } \\
\text { 2013b; Kay 2013b; } \\
\text { Murphy 2013; McPar- } \\
\text { land 2013c; Simpson } \\
\text { 2013a }\end{array}$ & $\begin{array}{l}\text { "scattered incidents of protest that inconvenience others are a surefire way } \\
\text { of dissipating support for the aboriginal cause" (Simpson 2013a) } \\
\text { "Some chiefs threaten to blockade the country next week. This will not } \\
\text { be progress. It will harm their cause and undermine the rule of law" } \\
\text { (Gibson 2013) } \\
\text { "hunger strikes have a way of reducing complex issues to the most simplest } \\
\text { elements" (Blatchford 2012) } \\
\text { "to imagine that problems of poverty, ill health and poor education are best } \\
\text { addressed-let alone solved-by histrionic threats, social-mediated mob } \\
\text { scenes or blocked roads or rail lines is a dangerous delusion" (Foster } \\
\text { 2013) } \\
\text { "trending on twitter is hardly a substitute for getting down to genuinely } \\
\text { 'hard work"" (Foster 2013) } \\
\text { "the Prime Minister is focused squarely on the art of the possible... it is } \\
\text { ironic, then, that the very approach he avoids is the one Idle No More } \\
\text { has embodied" (Carlson 2013) } \\
\text { "the quest for native dignity through other, more symbolic ways, often is ex- } \\
\text { pressed in such a theatrical and desperate-seeming fashion" (Kay 2013b) } \\
\text { "they want a new leader who will get with the program and limit himself } \\
\text { to loudly making demands, with no intention of ever having them met" } \\
\text { (McParland 2013c) }\end{array}$ \\
\hline $\begin{array}{l}\text { Accuse oppo- } \\
\text { nents of violat- } \\
\text { ing norms of } \\
\text { moderation }\end{array}$ & $\begin{array}{l}\text { Blatchford 2012; } \\
\text { Brazeau 2013; Coates } \\
\text { 2013; Coyne 2013a, } \\
\text { 2013b; Flanagan } \\
\text { 2013; Foster 2013; } \\
\text { Gibson 2013; Gurney } \\
\text { 2013; Ibbitson 2013b, } \\
\text { 2013c; Ivison 2013a; } \\
\text { McParland 2013b, } \\
\text { 2013c; Murphy 2013; } \\
\text { Simpson 2013a; Wid- } \\
\text { dowson } 2013\end{array}$ & $\begin{array}{l}\text { "The obvious conflict between reality and dream pulls some aboriginals } \\
\text { to warrior societies; others to dealing with the "crown' at all" (Simpson } \\
2013 a \text { ) } \\
\text { "The reaction was venomous" (Ivison 2013a) } \\
\text { "That is highly charged language" (Ivison 2013a) } \\
\text { "The fundamentalists seek to polarize the debate" (Coyne 2013b) } \\
\text { "Going all radical, hitting the racial/racist buttons" (Murphy 2013) }\end{array}$ \\
\hline
\end{tabular}


Table 1, cont'd.

\begin{tabular}{|c|c|c|}
\hline $\begin{array}{c}\text { Rhetorical } \\
\text { Strategy }\end{array}$ & Article & Examples \\
\hline $\begin{array}{l}\text { Accusations of } \\
\text { inconsistency }\end{array}$ & $\begin{array}{l}\text { Carlson 2013; Coyne } \\
\text { 2013a; Flanagan 2012, } \\
\text { 2013; Foster 2013; } \\
\text { Gibson 2013; Ivison } \\
\text { 2013a; McParland } \\
\text { 2013b, 2013c }\end{array}$ & $\begin{array}{l}\text { "surfacing spokespeople demand a shifting grab bag of change" (Gibson } \\
\text { "the movement has not made any specific demands or proposed tangible so- } \\
\text { lutions, spiraling instead into an amalgam of grievances" (Carlson 2013) } \\
\text { "The movement, with its vast and ill-defined agenda, its vague and shifting } \\
\text { demands, its many different self- appointed spokespersons, is open to } \\
\text { any number of different interpretations" (Coyne 2013a) } \\
\text { "conflicting nature of native complaints" (McParland 2013b) } \\
\text { "What are the aims of The Cause? No one is really quite sure: just as with } \\
\text { Occupy, the Idle forces are disparate and leaderless, a great mass of con- } \\
\text { flicting emotions" (McParland 2013c) }\end{array}$ \\
\hline $\begin{array}{c}\text { Consistency also } \\
\text { problematized }\end{array}$ & $\begin{array}{l}\text { Blatchford 2012; } \\
\text { Coyne 2013b; Gibson } \\
\text { 2013; Gurney 2013; } \\
\text { Ibbitson 2013d; Kay } \\
\text { 2013b; McParland } \\
\text { 2013c; Simpson 2013a, } \\
\text { 2013b }\end{array}$ & $\begin{array}{l}\text { "Chief Spence has attracted various predictable public adherents to her } \\
\text { cause" (Simpson 2013a) } \\
\text { "Some [demands] are to be expected, such as the call for more money" } \\
\text { (Gibson 2013) } \\
\text { "horse manure that usually accompanies native protests"(Blatchford 2012) } \\
\text { "Rarely has the penchant of native leaders for what a former prime min- } \\
\text { ister's chief of staff, Derek Burney, has called 'theology' been on such } \\
\text { open display... [ideologues] prefer to dwell on the inherent nature of } \\
\text { aboriginal rights and the spiritual joys of communal ownership" (Coyne } \\
\text { 2013b) } \\
\text { "Idle No More/Arab Spring, it's all one and the same. As long as you're } \\
\text { angry at the existing order, one membership card gets you universal ac- } \\
\text { cess" (McParland 2013c) }\end{array}$ \\
\hline $\begin{array}{l}\text { Question rep- } \\
\text { resentativeness } \\
\text { of opponent's } \\
\text { support }\end{array}$ & $\begin{array}{l}\text { Carlson 2013; Coates } \\
\text { 2013; Coyne 2013b; } \\
\text { Gagnon 2013; Ib- } \\
\text { bitson 2013c; Ivison } \\
\text { 2013a; McParland } \\
\text { 2013a, 2013b, 2013c } \\
\text { Simpson 2013a, 2013b }\end{array}$ & $\begin{array}{l}\text { "First nations issues ranked at the very bottom in public importance" (Ib- } \\
\text { bitson 2013c) } \\
\text { "According to a recent CROP survey, more than three-quarters of Quebeck- } \\
\text { ers hadn't even heard of the movement [...] Quite a few young Quebec } \\
\text { Indians now refuse to play the 'victim' card " (Gagnon 2013) } \\
\text { "for a determined few, it sounds like due process requires a patience they no } \\
\text { longer possess" (Ivison } 2013 a \text { ) } \\
\text { "as more and more putative leaders have jumped in front of the parade" } \\
\text { (Coyne } 2013 \text { a) } \\
\text { "By their decision to participate, Atleo and his supporters were not just star- } \\
\text { ing down the demands of what I've called the fundamentalists" (Coyne } \\
\text { 2013b) } \\
\text { "Mr. Atleo's AFN was divided internally, and divided again against more } \\
\text { radical elements in the Idle No More movement" (McParland 2013a) } \\
\text { "But Idle No More's co-founder has distanced [blockades] from the pro- } \\
\text { tests... emphasizing that the movement is devoted to 'peaceful' educa- } \\
\text { tion events" (McParland 2013b) }\end{array}$ \\
\hline $\begin{array}{l}\text { Accuse oppo- } \\
\text { nents of infring- } \\
\text { ing on the rights } \\
\text { of others }\end{array}$ & $\begin{array}{l}\text { Blatchford 2012; Gur- } \\
\text { ney 2013; McParland } \\
2013 b, 2013 c\end{array}$ & $\begin{array}{l}\text { "a prime minister should not be blackmailed into doing what any group or } \\
\text { individual wants" (Simpson 2013a) } \\
\text { "It is tempting to see the action as one of intimidation, if not terrorism... } \\
\text { holding the state hostage" (Blatchford 2012) } \\
\text { "[Canadians] are likely unwilling to be held to ransom by the most radical } \\
\text { elements of that community" (McParland 2013b) } \\
\text { "It is increasingly clear that the OPP's established procedures for dealing } \\
\text { with native protests have relegated law enforcement to a second-tier pri- } \\
\text { ority" (Gurney 2013) }\end{array}$ \\
\hline
\end{tabular}


The presentation of realism is also particularly important in the construction of Aboriginal peoples as irrational, emotional, and naïve. Reference to the unrealistic character of Aboriginal demands or their lack of realpolitik was so pervasive in my data that they were present in almost all of the articles I analyzed. These were riddled with evaluative adjectives such as dreamy, romantic, unrealistic, wishful, nonsense, mythical, simplistic, shallow, and pseudo-academic_-all emphasizing the notion of non-factuality of $\mathrm{Ab}$ original claims. This is also supported by the presupposition that these falsities or unrealisms boil down to an error in judgment caused by emotion or belief. For example, Aboriginal people were said to dream, romanticize, fantasize, hope, and dwell-leading to their having a sense of entitlement, rather than actual entitlement, and the perception that they are owners of the land rather than their real and legally-defined Aborigi-

Table 2. Word choice of op-ed columnists in The Globe and Mail and the National Post when writing about Idle No More, December 2012-January 2013.

\begin{tabular}{|c|c|}
\hline $\begin{array}{l}\text { Discrediting } \\
\text { tactic }\end{array}$ & Examples \\
\hline Tone policing & $\begin{array}{l}\text { "fierce" (Flanagan 2012); "inflammatory, but inaccurate" (Flanagan 2012); "aggressive tone" (Wid- } \\
\text { dowson 2013); "discontent" (Ibbitson 2013b); "sound and fury"(Gibson 2013); "angry chorus" } \\
\text { (Gagnon 2013); "noise of social protest" (Ibbitson 2013d); "inspires their wrath" (Ibbitson 2013d); } \\
\text { "anger... could trump any willingness to cooperate" (Ibbitson 2013d); "hue and cry" (Flanagan } \\
\text { 2013); "The reaction was venomous" (Ivison 2013a); "half-threats" (Murphy 2013); "worrisome } \\
\text { is the tone, the ratcheting up of frictions" (Murphy 2013); "national upsurge of native anger" } \\
\text { (McParland 2013a); "angry crowds of natives" (McParland 2013b); "the great angry disaffected } \\
\text { world of progressive opposition to The Man" (McParland 2013c); "angry" (McParland 2013c); "a } \\
\text { great mass of conflicting emotions" (McParland 2013c); "loudly making demands, with no intention } \\
\text { of ever having them met" (McParland 2013c); "we are being told loudly, provocatively, and angrily" } \\
\text { (Brazeau 2013) }\end{array}$ \\
\hline $\begin{array}{l}\text { Description as } \\
\text { drama/circus }\end{array}$ & $\begin{array}{l}\text { "winter of native discontent" (Ibbitson 2013c); "It is not a comedy of errors but a tragedy of er- } \\
\text { rors" (Ibbitson 2013c); "angry chorus" (Gagnon 2013); "the parade" (Coyne 2013a); "circus-like" } \\
\text { (Kay 2013b); "the quest for native dignity through other, more symbolic ways, often is expressed in } \\
\text { such a theatrical and desperate-seeming fashion" (Kay 2013b); "great melodramatic appeal" (Mur- } \\
\text { phy 2013); "chaos" (McParland 2013c); "[Spence's] liquid diet performance” (Brazeau 2013) }\end{array}$ \\
\hline $\begin{array}{l}\text { Description as } \\
\text { violent/radical }\end{array}$ & $\begin{array}{l}\text { "warrior society" (Simpson 2013a); "radicals" (Ibbitson 2013a); "native protests that threaten to } \\
\text { escalate" (Ibbitson 2013c); "extremists" (Ibbitson 2013c); "the militant tendency within the native } \\
\text { movement" (Ibbitson 2013c); "The wild card is anarchy [... if] the Idle No More activists escalate } \\
\text { their demonstrations to the point where there is risk of violence or serious economic disruption" } \\
\text { (Ibbitson 2013c); "aboriginal militants [at Oka]" (Gagnon 2013); "insurgency [against Atleo]" } \\
\text { (Ibbitson 2013d); "more radical [leaders]" (Flanagan 2013); "[INM] has the potential to radicalize } \\
\text { a generation" (Ivison 2013a); "[fundamentalists] seek to polarize debate" (Coyne 2013b); "native } \\
\text { violence [in Caledonia]" (McParland 2013b; Gurney 2013) }\end{array}$ \\
\hline $\begin{array}{l}\text { Description as } \\
\text { naïve/entitled }\end{array}$ & 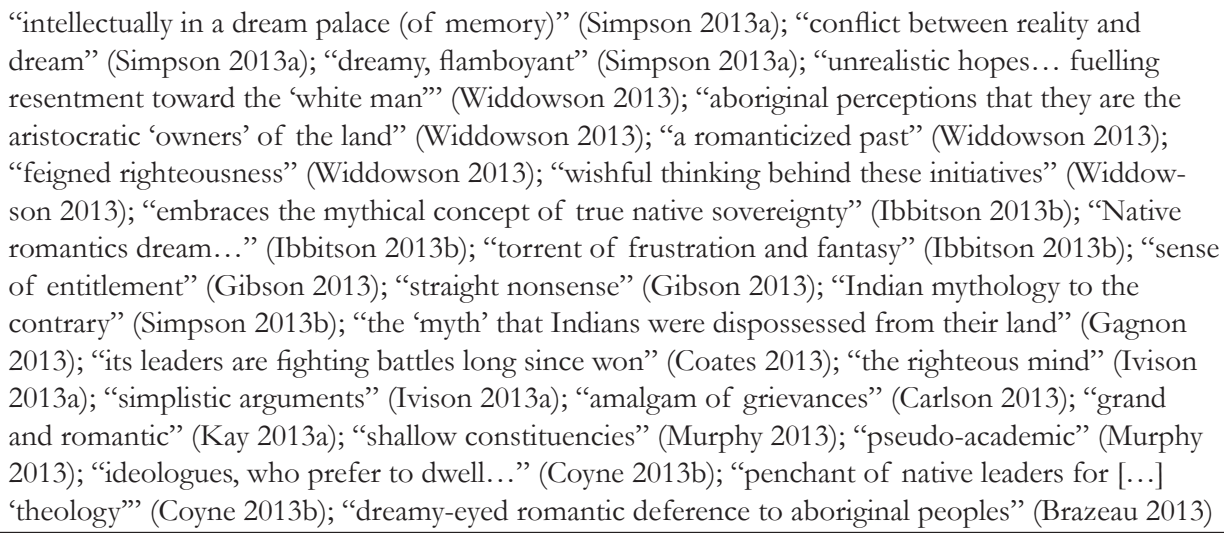 \\
\hline
\end{tabular}


nal treaty right to it. This gives the impression of Aboriginal peoples merely feeling dispossessed rather than being actually dispossessed and that their history, traditional use, and historic claims to the land are mythological. Substantive claims and demands, such as homeland return and restitution or even calls for an inquiry into missing and murdered Aboriginal women, are minimized as mere grievances.

When it comes to social protest, the representation of one's opponents as irrational also tended to rely on the notion of a primitive and regressive nature of crowd action. This depends upon the assumption that the individual is immersed in an anonymous mass and subsequently loses identity and rationality; the construction is of followers who jump on bandwagons (see Tables 1 and 2).

The rhetorical procedures for constructing the effect of moderation, and the effect of extremism, are publicly available and collectively shared resources in both their familiarity and in their appeal to prudential values of moderation and practicality. These constructions sustain a framing of debate which contain certain premises and assumptions about what can be considered appropriate and realistic political action. This contributes to structuring discussion and conflict by reinforcing among readers notions of legitimate/illegitimate means to incite and enact change.

However, in the articles I analyzed, Idle No More was constructed as a threat to the Canadian social fabric not just in terms of civil unrest and public protest that could escalate, but also in terms of deeper cultural assumptions about history and the (perceived) trajectory of social organization. Journalists were not only concerned with problematizing protest in itself, but also engaged in theorizing the relationship between Aboriginal people and the rest of Canadian society through historical accounts.

\section{History and the Articulation of Continuity/Discontinuity}

The colonist makes history. His life is an epic, an odyssey. He is invested with the very beginning: 'We made this land.'
He is the guarantor for its existence: 'If we leave, all will be lost, and this land will return to the Dark Ages.' Opposite him, a listless being wasted away by fevers and consumed by 'ancestral customs' compose a virtually petrified background to the innovative dynamism of colonial mercantilism. The colonist makes history and he knows it [Fanon 2004, 15].

One of the fundamental conflicts Wetherell and Potter identified in their interviews with Pākehā settlers on Māori social policy was in regard to history and change, and a particular concern with how much of the past should be carried into the future. They write that in these accounts: "History seems to be articulated in two forms either as continuity or as discontinuity. These formulations appear oppositional but they in fact feed off each other" (Wetherell and Potter 1992, 183).

Nominalization is a key form of moral evaluation and a common technique used in accounts of the changes that have occurred over history. These evaluations are obscured in the nominalization of social and cultural processes (e.g. "modernization") in such a way that makes them appear natural. Wetherell and Potter (1992, 137) argue that colonial history can therefore be "reconstructed as a story of clashing values, the modern against the traditional, as opposed to a story of conflicting interests, power relations and exploitation. There is an inevitability and acceptability in the notion of 'culture contact' not found in the rhetoric of annexation, conquest and oppression." In accounts such as these, the events of history come to seem agentless, abstracted, and denatured as part of larger natural processes, helping to veil and deflect responsibility.

Take this excerpt from Jonathan Kay's (2013a) op-ed piece 'What's wrong with remote native reserves-Let's ask a veteran doctor who worked there" in the National Post, containing a historical narrative offered in the wake of the release of an audit report of Chief Theresa Spence's reserve, Attawapiskat, or what Kay calls "the land that accounting forgot." $\mathrm{He}$ writes: 
... as modernization set in, the old ways were largely abandoned, and Natives increasingly became sedentary, like the rest of us. Men lost their traditional jobs as their economy lost its relevance in the modern world. Furs went out of style. Hunting and fishing could no longer support the growing population; and, out of necessity, social welfare became the new normal.

Notice how, in this historical narrative of the economy of a remote northern community, change is entirely agentless. This use of nominalization aids in substituting one context for another: colonialism is subtly reworked as neutral and a matter of course. In this way, modernization becomes mechanical or natural and unproblematic. This works to conceal power relations and reduce our sense of what was truly involved in these transactions (Hitchings 2013). Actions in themselves are prioritized over attributing responsibility to the colonial agents dispatched with the purpose of destroying Indigenous economies. For example, Kay writes that Aboriginal peoples "increasingly became sedentary, like the rest of us," but accounts of forced relocation do not feature in his narrative.

Kay writes that hunting and fishing were replaced with the receipt of welfare, which became "normal" —an idea that has come to carry a negative connotation. In the discourse of meritocracy, welfare is meant to be a shameful last resort; the implication is that if welfare is normalized, it amounts to pathologically lazy individuals and a dysfunctional society. What is being slyly referred to, in the case of First Nations, are transfer payments. The subtle implications of recasting treaty entitlements as welfare are therefore potent ideological resources in the denigration of Aboriginal peoples.

The claim that the traditional economy "lost its relevance" is particularly telling of how Kay sees society. This assessment suggests to the reader that complex socioeconomic and political systems that sustained an immense variety of Aboriginal societies since time immemorial are irrelevant in a modern world. The assumption of his version of history therefore relies upon the articulation of continuity and discontinuity, in the sense that the story of modernization is one of continual improvement, as long as only certain paths are followed. Aboriginal men did not lose their jobs because they were irrelevant, nor simply because of the dictates of the fur market. It came about due to the setting up of systems that privileged Europeans at every level, including, as we see here, the privilege of writing histories which justify exclusion and oppression as a simple matter of the "old ways" versus the "new."

\section{Golden Future or Dark Future}

Wetherell and Potter $(1992,184)$ found that Pākehā settler discourse painted an image of a "golden future" when discussing intergroup relations with Māori. They wrote that the future was considered golden "to the extent that history becomes a story of continual improvement."

Here is another text example from Rex Murphy's column "Natives need to tone down the anger" (National Post, January 12, 2013). In describing what he calls "a moment when moral heroes may be made," Murphy's assessment oscillates between a completely unnamed and antagonistic Aboriginal population and a sincere, sympathetic population of Canadian citizens:

Going all radical, hitting the racial/racist buttons and constant invocations of empty pseudo-academic framings of "colonialist, settler, imperialist" mentalities do nothing but burn time, waste energy and alienate a large section of the public.

The biggest point continually to note is how deep a pool of genuine goodwill exists in Canada; how much most Canadians, certainly over the last three decades-perhaps because of the lingering guilt over residential schools_-feverishly want an honest reconciliation.... There's been a rawness to the talk and exchanges of the last few weeks, a reaching for the hard words and the ugly ones, that we have not seen-gratefully-for a long time.... A refusal to acknowledge the 
birth of new attitudes and sensitivities will seriously, maybe fatally, wound the effort at reform and reconciliation.

Comparison in discourse almost always has a legitimatory/delegitimatory function (van Leeuwen 2007,99 ), and in this case the use of contrast is a powerful way to convince settler $\mathrm{Ca}$ nadians to pick a side, or, more accurately, feel good about being presumed to be on the right side. Both sides are further presented as actively struggling against each other, but for settlers it is in order to appease and reconcile.

Murphy's primary linguistic tactic for delegitimizing, deflecting, and minimizing is to suggest that the tone of discussion is more important than its content. Thus, Aboriginal people and their allies should not be listened to if they are too angry, aggressive, "hit the racist button," or invoke "empty" framings and mentalities. Apparently the only mentality Murphy is willing to engage with are those with whom he agrees, and only after they spend the majority of the discussion acknowledging the intellectual and emotional labour on the part of settler Canadians over the past three decades at least. Aboriginal people and their allies are again being constructed and disqualified from the conversation as unreasonable, unfair, and as possibly unable to engage in productive dialogue. It is evident in this example that critically speaking about the continuing oppression of peoples is therefore minimized as mere impoliteness and rudeness, seemingly excusing readers from actually listening to the "hard words and the ugly ones."

Another major point to draw from this is a possible dilemma between the idea that injustices should be righted, but that Canadians must also distance themselves from the actions of a crueler time. Inasmuch as one acknowledges the "birth of new attitudes," the terms for reconciliation are implied to involve forgetting past injustices. At the very least, this implication mitigates settler Canadian wrongdoing and lessens the weight of Aboriginal claims for justice. What are the consequences of the construction of reconciliation (cf. James 2012; Woolford 2004; Corntassel and Holder 2008) on these terms? Murphy's claims are made out as statements of fact, but actually rely upon - and are justified by — an evaluative framework that denies the possibility of informed and reciprocal discussion. Any real history is elided and a history of settlers as having endeavored to reach accommodation is substituted.

Wetherell and Potter (1992, 184) noticed that Pākehā New Zealanders also envisioned another possible outcome, seen as a "dark future": "[They] will outline pessimistic and apocalyptic accounts of inevitable doom, chaos, failure and the barbaric times to come." In these cases, once again, moderation is praised against the backdrop of a threatening and destructive extremism that will damage the status quo. These mythopoetic exaggerations are an attempt to link nonviolent political activism to isolated and more uncommon forms of Aboriginal protest (such as Oka). In this view, Aboriginal protests always threaten to escalate, stir up racial division, derail progress, and cause serious damage to persons or property.

What is significant, according to Wetherell and Potter, is the different discursive contexts in which the two versions of a 'golden future' and a 'dark future' are utilized. Opinion writers were concerned at how increasing tensions and disruption resulting from Idle No More protests might mar the future, yet when justifying the status quo and current social and political context, the future once again became golden. The continuous view of history and the golden future pose a difficulty to the critic, as Wetherell and Potter (1992, 185) write:

[They] are powerful argumentative resources not least because it becomes irrational from this perspective to question the current form of society... the characteristics which make the future golden... increasing technological benefits, rational administration, civilized values, and charitable good-will.... This is the way the world is going and resistance thus becomes quixotic. The critic is skillfully caught in a dilemma-how can one argue against such 'obvious' good things and such optimism, without appearing to advocate a return to 'the bad old days'? 
The Idle No More movement is likewise cast as irrational not only for harboring extremists who disturb the peaceful resting state of the status quo, but also for critiquing the spirit of optimism contained in the notion of a society becoming increasingly just, equitable, efficient, and comfortable every day.

The discontinuous view of history is a potent formulation and resource for justification and (de)legitimization. Its emphasis on the distance of history makes the past seem foreign to the modern, "civilized" eye. Injustices are presented as characteristics of history, and "the violence of colonial times can be firmly and safely placed in history and disconnected from the present. Again the critic is silenced" (Wetherell and Potter 1992, 185).

\section{DisCUSSION}

As Wayne Warry (2007) suggests, it is confusion about the nature of culture that is key to misunderstandings between Indigenous peoples and settlers. Traditions are often confused with static customary practices as opposed to ways of thinking that can and do change with the times. This is the assumption that underlies the common argument that Indigenous peoples have been too tainted by modernity to warrant special status or nationhood. However, when culture is perceived in this way — as deeply equated with the past - the implication is that all modern Indigenous peoples "become liable to damage, by definition" (Wetherell and Potter 1992, 130): their participation in "modern" activities is taken as evidence that their culture is losing its relevance, and loss of specific cultural practices is seen as loss of all culture (Warry 2007, 89). Moreover, this ignores how much indigenous culture has been sustained despite policies explicitly aimed at assimilation and the complex negotiations that take place on the part of Aboriginal individuals and communities.

There is, as one might then imagine, a pervasive misunderstanding that indigenous peoples are fighting to preserve the ways of their past, but in fact they are fighting for their right to have a say in their own future (Maybury-Lewis 2001). As Neu and Therrien (2003, 3) write: "They see clearly that they are being dispossessed of their traditional territories, not for the sake of the country as a whole, but for the sake of private profit." Vermette $(2012,18)$ argues that the cheapest and most convenient way to achieve such dispossession is to be more inclusive:

Equality is meaningless without an examination of the context in which it is grounded. Once one realizes that 'economic equality' operates largely on the presumption that Aboriginal peoples are (or want to become) marauding capitalists (and the corresponding realization that Aboriginal cultures are not capitalist cultures) the idea of equality is quickly shattered. Any initiatives that reach out to Aboriginal peoples in this way do so at the expense of Aboriginal ways of life.

Without socioeconomic analysis, there can be no real understanding of such abstractions as progress and development, and, as Fairclough $(2003,95)$ writes, "no real sense of its contingency-how changing things at one level could produce different possibilities." Many contemporary policy texts - and this can be extended to mainstream media_can therefore be seen to "limit policy options by portraying the socio-economic order as simply given, an unquestionable and inevitable horizon... essential rather than contingent, and without time depth" (Fairclough 2003, 95).

The idea that assimilation is the solution to current marginalization of Indigenous peoples is not simply right wing, but a predominant mainstream view. Opinion journalism makes the commonsense assimilationist approach to Aboriginal issues quite accessible to most within the general public, as it utilizes "the symbolically-potent rhetoric of equality" (Cairns 2000, 73) and invokes the reader's sense of fairness. As Wetherell and Potter (1992, 182) write: "Equality allows for passionate argument and forceful indignation at its supposed violation because the ethical grounds of argument seem so well established. Liberal principles are firmly entrenched as common sense." The idea is that race-based policies should be rejected in a democratic society that does not discriminate on the basis of race (Warry 2007). However, Canadians are often blind to or 
ignore the times when they were privileged in policies that directly discriminated against $\mathrm{Ab}$ original peoples. The inherent double standard is that Aboriginal people are accused of dwelling on their rights, but settlers do not question their own rights to privately own or have access to their own culturally relevant institutions.

We can therefore see why it is so important to recognize the multi-referential nature of arguments and interpretive resources (Wetherell and Potter 1992, 71), as race can be mobilized in different ways at different times, and for very different ends. In fact, the concept of race poses some difficulties to the critic, particularly when considering the popular approach to racist discourse which exclusively focuses on truth and falsity. As Wetherell and Potter $(1992,68)$ have argued, these views are not "an automatic guarantee of effective anti-racist practice" and can actually undermine anti-racist practice "with their under-developed concepts of the social nature of the 'real'." For instance: that racial slurs are considered to have been banished from politically-correct public discourse is taken as an indication that our society has become more culturally enlightened; that Aboriginal symbols are included in schools and national events is seen as fostering inclusiveness; and that individual $\mathrm{Ab}$ original people can compete with non-Aboriginal people in the marketplace is said to prove that our society is one of equal opportunity. The ideological effect of these kinds of explanations is the obfuscation of exploitative social and economic relations. To quote Alfred (1999, xv):

From the outside, the intensity of the crisis is obscured by the smokescreen of efforts to reduce the most obvious signs of social deprivation and increase the material wealth within Native communities. It is commonly thought that allowing indigenous people a reasonable standard of living will solve all their problems. But there is more to justice than equity. Of course indigenous people have a right to a standard of living equal to that of others. But to stop there and continue to deny their nationhood is to accept the European genocide of 500 years.

\section{Conclusion}

Because people only know tiny portions of social life, they "are pressed to rely on mass media for bearings in an obscure and shifting world"; therefore, more than any other institution, "the media specialize in orchestrating everyday consciousness" (Gitlin 1980, 2). The rhetoric, imagery, and underlying common stock of knowledge which writers assume their audience shares form the basis of reciprocity between news producers and consumers. Although the establishment, maintenance, and contestation of the social dominance of particular social groups is neither automatic nor transparent, the ability to implicitly justify oppressive and exploitative relations is an essential feature of the modern state.

Assimilationist arguments and policies of today mirror the spirit and purpose of Duncan Campbell Scott's "Indian problem" which mandated one of the most horrific policies in the genocide of Indigenous peoples in North America. Yet the palatability of these arguments is increased through the journalistic appeal to popular Canadian self-perceptions of fairness, sympathy, and the assumption of a progressive present.

Mainstream opinion journalism is premised on the colonial narrative. By diverting discourse away from substantive issues such as homeland return and restitution, they bypass opportunities to honestly interrogate the colonial relationship Canada has with Indigenous peoples in a way that any real reconciliation would require. Mainstream journalists have therefore produced a "politically salient misreading" (Eudaily 2004) of the protest tactics of the Idle No More movement by conflating such tactics with the conclusion that activists accept the rules of the game laid out by liberal democratic principles. In this way, Indigenous peoples' movements which set out to transform relations between settler and Indigenous communities can be depoliticized in that their goals are presented as being internal to political liberalism and can be made the objects of problem solving rather than the agents of problematization for government. 


\section{ACKNOWLEDGEMENTS}

This paper is an abbreviated form of an Honours thesis submitted to the Anthropology department at St. Thomas University, New Brunswick, Canada. This research was supervised by Dr. Craig Proulx.

\section{References Cited}

Alfred, Taiaiake.1999. Peace, Power and Righteousness: An Indigenous Manifesto. Toronto: Oxford University Press.

Ashcroft, Bill, Gareth Griffiths, and Helen Tiffin. 1998. Key Concepts in Post-Colonial Studies. New York: Routledge.

Blatchford, Christie. 2012. "Inevitable Puffery and Horse Manure Surrounds Hunger Strike while Real Aboriginal Problems Forgotten." National Post, December 27.

Brazeau, Patrick. 2013. “The Unsolved Mysteries of Aboriginal Affairs and Northern Development Canada." National Post, January 18.

Cairns, Alan C. 2000. Citizens Plus: Aboriginal Peoples and the Canadian State. Vancouver: University of British Columbia Press.

Carlson, Kathryn B. 2013. "No Chief Complaint: Idle No More's Vague Demands Butting Up against PM's Pragmatism." National Post, January 4.

Chrisjohn, Robin, and Sherri Young. 2006. The Circle Game: Shadows and Substance in the Indian Residential School Experience in Canada. Penticton: Theytus Books.

Coates, Ken. 2013. “Chief Atleo’s New Model of Aboriginal Politics." The Globe and Mail, January 17.

Corntassel, JefF, and Cindy Holder. 2008. "Who's Sorry Now? Government Apologies, Truth Commissions, and Indigenous Self-Determination in Australia, Canada, Guatemala and Peru." Human Rights Review 9(4):465-489.

Coyne, Andrew. 2013a. "Meeting with Harper Won't Settle Aboriginal People's Problems." National Post, January 7.

2013b. "Atleo Was Courageous to Meet with Harper as His Constituency Openly Revolts." National Post, January 11.

Eudaily, Sean P. 2004. The Present Politics of the
Past: Indigenous Legal Activism and Resistance to (Neo)Liberal Governmentality. New York: Routledge.

Fairclough, Norman. 2003. Analyzing Discourse: Textual Analysis and Social Research. London and New York: Routledge.

Fairclough, Norman, and Ruth Wodak. 1997. "Critical Discourse Analysis." In Discourse Studies: A Multidisciplinary Introduction, Vol. 2. Discourse as Social Interaction, Teun A. van Dijk, ed., pp. 258-84. London: Sage.

Fanon, Frantz. 2004. The Wretched of the Earth. Richard Philcox, trans. New York: Grove Press.

Flanagan, Tom. 2012. "Bill C-45 Simply Makes It Easier for First Nations to Lease Land." The Globe and Mail, December 29.

- 2013. "Native Talks with the Crown Challenge Canada's Very Existence." The Globe and Mail, January 25.

Fleras, Augie, and Jean L. Elliot. 1992. The Nations Within: Aboriginal-State Relations in Canada, the United States and New Zealand. Toronto: Oxford University Press.

Foster, Peter. 2013. "Misguided Hunger Strike Is Manufacturing Dissent.” National Post, January 3.

Fowler, Roger, Bob Hodge, Gunther Kress, And Tony Trew. 1979. Language and Control. London: Routledge

Furniss, Elizabeth. 2001. "Aboriginal Justice, the Media, and the Symbolic Management of Aboriginal/Euro-Canadian Relations." American Indian Culture and Research Journal 25:21-36.

Gagnon, Lysiane. 2013. "Quebec's Special Relationship with Its Native Peoples." The Globe and Mail, January 16.

Gibson, Gordon. 2013. "To Solve Native Issues, Focus More on the Indians and Less on the Chiefs." The Globe and Mail, January 13.

GitLIn, TodD. 1980. The Whole World is Watching. Berkeley: University of California Press.

Greenberg, Joshua. 2000. "Opinion Discourse and Canadian Newspapers: The Case of the Chinese 'Boat People."' Canadian Journal of Communication 25:517-537.

Grenier, Marc. 1994. "Native Indians in the English-Canadian Press." Media, Culture and 
Society 16:313-36.

Gurney, Matт. 2013. “OPP Commissioner Should Ask for the Army if Policing Blockades Proves Too 'Difficult'." National Post, January 16.

Hall, Stuart. 1982. "The Rediscovery of 'Ideology': Return of the Repressed in Media Studies" In Culture, Society and the Media, Michael Gurevitch, Tony Bennett, James Curran and Janet Woollacott, eds., pp. 52-86. New York: Methuen.

Harding, Robert. 2006. "Historical Representations of Aboriginal People in Canadian News Media." Discourse and Society 17(2):205-35.

Henry, Frances, and Carol Tator. 2002. Discourses of Domination: Racial Bias in the Canadian English-Language Press. Toronto: University of Toronto Press.

2000. "The Theory and Practice of

Democratic Racism in Canada." In Perspectives on Ethnicity in Canada: A Reader, Madeline A. Kallbach and Warren E. Kallbach, eds., pp. 285-302. Toronto: Harcourt Brace.

Hitchings, Henry. 2013. "The Dark Side of Verbs-as-Nouns." The New York Times, April 5. Electronic resource, http:/ opinionator.blogs. nytimes.com/2013/04/05/the-dark-side-ofverbs-as-nouns/?_r=0.

IbBitson, John. 2013a. "Truth Is More Complex than Attawapiskat Audit Can Tell Us." The Globe and Mail, January 8.

. 2013b. "Native Romantics Dream of a King Who Will Never Come." The Globe and Mail, January 10.

2. 2013c. "Harper Needs to Stay the Course in Winter of Native Discontent." The Globe and Mail, January 14.

. 2013d. "Conservatives Have Faith in

Their First-Nations Agenda. Will Others." The Globe and Mail, January 24.

Ivison, JoHn. 2013a. "Simplistic Arguments from Theresa Spence, Idle No More Could Have Tragic Consequences for Natives." National Post, January 2.

. 2013b. “Theresa Spence's Hunger Strike Obscures the Key First Nations Issue, Resource Revenue Sharing." National Post, January 8 .
JAmes, MAтT. 2012. "A Carnival of Truth? Knowledge, Ignorance and the Canadian Truth and Reconciliation Commission." International Journal of Transitional Justice 6(1):1-23.

Jonas, George. 2013. "Residential Schools Were a Savage Solution to a Lingering Problem." National Post, January 16.

Kay, Jonathan. 2013a. "What's Wrong with Remote Native Reserves: Let's Ask a Veteran Doctor Who Worked There." National Post, January 10.

_. 2013b. "Native Dignity Will Come Only from Self-Sufficiency, Not Grand Gestures in Ottawa." National Post, January 11.

Kress, Gunther, And Robert Hodge. 1979. Language as Ideology. London: Routledge \& Kegan Paul.

LeSLIE, JoHn. 1978. The Historical Development of the Indian Act, 2nd edition. Ottawa: Department of Indian Affairs and Northern Development, Treaties and Historical Research Branch.

Martin, Lawrence. 2013. "Another Tragic Chapter in Canada's Aboriginal Saga...." The Globe and Mail, January 8.

Maybury-Lewis, David. 2001. Indigenous Peoples, Ethnic Groups, and the State, 2nd Edition. Boston: Allyn and Bacon.

McParland, Kelly. 2013a. "Idle No More Is an Opportunity for Harper to Seize." National Post, January 14.

—. 2013b. “OPP Bromides Won't Satisfy Ontarians if Natives Follow Through on Threats of Disruption." National Post, January 16.

. 2013c. "Idle No More Has Been Seized by Occupying Forces.” National Post, January 17.

Miller, John. 2005. "Ipperwash and the Media: A Critical Discourse Analysis of How the Story was Covered." Draft Report. Electronic resource, accessed February 1, 2013. http:// firstnationsstudies.uwo.ca/FNS3001GIpperwash_and_media.pdf.

Murphy, Rex. 2013. "Natives Need to Tone Down the Anger." National Post, January 12.

Neu, Dean, and Richard Therrien. 2003. Accounting for Genocide: Canada's Bureaucratic Assault 
on Aboriginal People. Halifax: Fernwood Publishing.

Pietikainen, Sari. 2003. "Indigenous Identity in Print: Representations of the Sami in News Discourse." Discourse and Society 14(5):581-609. Proulx, Craig. 2011. "A Critical Discourse Analysis of John Stackhouse's 'Welcome to Harlem on the Prairies'." In Aboriginal Peoples in Canadian Cities: Transformations and Continuities, Heather A. Howard and Craig Proulx, eds., pp. 143-170. Waterloo: Wilfred Laurier University Press.

SAunders, Doug. 2013. "What Kind of Nation Is a First Nation-We Need to Decide." The Globe and Mail, January 12.

SAwyer, R. KeIth. 2002. "A Discourse on Discourse: An Archaeological History of an Intellectual Concept." Cultural Studies 16:433-456.

Shapiro, Michael J. 1981. Language and Political Understanding. New Haven: Yale University Press.

Simpson, JefFrey. 2013a. "Too Many First Nations People Live in a Dream Palace." The Globe and Mail, January 5.

-. 2013b. "So Aboriginals Are Divided. Aren't We All." The Globe and Mail, January 16.

Singer, Benjamin D. 1982. "Minorities and the Media: A Content Analysis of Native Canadians in the Daily Press." Canadian Review of Sociology and Anthropology 19(3):348-59.

SkeA, Warren H. 1993. "The Canadian Newspaper Industry's Portrayal of the Oka Crisis." Native Studies Review 9(1):15-31.

Szuchewycz, Bohdan. 2000. "Re-Pressing Racism: The Denial of Racism in the Canadian Press." Canadian Journal of Communications 25(4):497-514.

Teo, Peter. 2000. "Racism in the News: A Critical Discourse Analysis of News Reporting in Two Australian Newspapers." Discourse and Society 11(1):7-49.

van Dijk, Teun A. 1993. Elite Discourse and Racism. Newbury Park, CA: Sage.

VAN LeEuWEN, TheO. 2007. "Legitimation in Discourse and Communication." Discourse and Communication 1 (1):91-112.

Vermette, D'Arcy. 2012. "Inclusion is Killing Us.” Teaching Perspectives 17:18-19.
Vowel, Chelsea. 2012. "No, Things Are Not Getting Better for Canadian Natives.” National Post, December 24. http://fullcomment.nationalpost.com/2012/12/24/chelsea-vowelno-things-are-not-getting-better-for-canadiannatives/.

Warry, Wayne. 2007. Ending Denial: Understanding Aboriginal Issues. Peterborough: Broadview Press.

Wetherell, Margaret, and Jonathan Potter. 1992. Mapping the Language of Racism: Discourse and the Legitimation of Exploitation. New York: Columbia University Press.

Widdowson, Frances. 2013. "A 'Dream Palace' Built on Gas and Gold Won't Solve Aboriginal Poverty." The Globe and Mail, January 10.

WoOlford, ANDrew. 2004. "The Limits of Justice: Certainty, Affirmative Repair and Aboriginality." Journal of Human Rights 3(4):429-30. 